\title{
Uzaktan Eğitim İle Verilen İngilizce Dersine Yönelik Öğrenci Görüşleri: Muş Alparslan Üniversitesi Örneği*
}

\section{Students' Views On English Lesson Taught Through Distance Education: Muş Alparslan University Sample}

\author{
Ezlam Pepeler, ${ }^{a}$ Ramazan Özbek, ${ }^{\mathrm{b}}$ Yahya Adanır ${ }^{\mathrm{c}, * *}$ \\ ${ }^{a}$ Dr. Öğr. Üyesi, İnönü Üniversitesi, Eğitim Fakültesi, Eğitim Bilimleri Bölümü, 44280, Malatya/Türkiye. \\ ORCID: 0000-0002-8942-7590

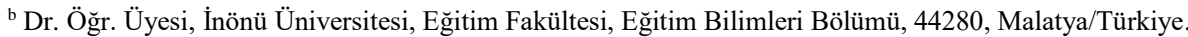 \\ ORCID: 0000-0002-6228-1624
}

c Okt., Muş Alparslan Üniversitesi, Rektörlük, 49250, Muş/Türkiye. ORCID: 0000-0003-2915-2334

\section{MAKALE BILLGİSI}

\section{Makale Geçmişi:}

Başvuru tarihi: 19 Ekim 2017

Düzeltme tarihi: 16 Aralı 2017

Kabul tarihi: 23 Aralık 2017

\section{Anahtar Kelimeler:}

Uzaktan Eğitim

İngilizce

Öğrenci Görüşleri

İkinci Dil Öğretimi/Öğrenimi

\section{ART ICLE INFO}

\section{Article history:}

Received 19 October 2017

Received in revised form 16 December 2017

Accepted 23 December 2017

\section{Keywords:}

Distance Education

English

Students' Views

Second Language Teaching/Learning

\section{ÖZ}

$\mathrm{Bu}$ araştırma, Muş Alparslan Üniversitesinde uzaktan eğitim ile verilen İngilizce dersine yönelik öğrenci görüşlerinin belirlenmesi amacıyla yapılmıştır. Araştırmada nicel araştırma yöntemlerinden betimsel tarama modeli kullanılmıştır. Araştırmanın evrenini 2016-2017 eğitim-öğretim yılında Muş Alparslan Üniversitesine bağlı fakülte ve yüksekokullarda öğrenim görmekte olup, 2016-2017 güz döneminde İngilizce dersini uzaktan eğitim yoluyla alan 2411 öğrenci oluşturmaktadır. Araştırmanın örneklemini ise 420 öğrenci oluşturmaktadır. Araştırmanın verilerini toplamak amacıyla 36 maddeden oluşan beşli Likert türünde Uzaktan Eğitimle Yürütülen Yabanc1 Dil I (İngilizce) Dersi Öğretim Programını Değerlendirme Ölçeği (İÖPDÖ) kullanılmıştır. Öğrencilerin uzaktan eğitim ile verilen İngilizce dersine yönelik görüşlerinin genel anlamda olumsuz olduğu ve en olumsuz boyutun ise ürün boyutu olduğu görülmüştür. Ayrıca, ögrencilerin Yabancı Dil I dersinin uzaktan eğitimle verilmesinin İngilizce bilgilerini geliştirmede etkili olmadığı görüşüne sahip oldukları görülmüştür.

\section{A B S T R A C T}

The aim of this study is to investigate the views of the students about English lesson which is taught through distance education at Muş Alparslan University. Descriptive survey model which is a quantitative research model has been used in the study. The universe of the research is composed of 2411 students who took English lesson through distance education at Muş Alparslan University during the autumn semester of 2016-2017 academic year. In order to collect the data of the study, a 5 Likert type scale of 36 items with the name of The Scale of Evaluating the Curriculum of Foreign Language 1 (English) Lesson Taught Through Distance Education (SECFL) has been used. Students' views about the English lesson taught through distance education are generally negative and the most negative component is the product component. Moreover, the students are of the opinion that the English lesson taught through distance education isn't effective in developing their English language level.

\section{Giriş}

Günümüzde bilgi ve teknolojinin baş döndürücü bir hızda gelişmesi, en başta bilgiye ulaşmanın kolaylaşması olmak üzere birçok olanak sunmaktadır. $\mathrm{Bu}$ baş döndürücü gelişmeler bilgi toplumlarının ortaya çıkmasını sağlayarak, toplumların teknolojik gelişmeleri izlemeleri ve kendilerine uyarlamalarını zorunlu hale getirmiştir ve bu hılı gelişmeler sayesinde eğitim-öğretim süreçlerinde kullanılabilecek araç gereçlere de her gün yenileri eklenmektedir (Kutluca ve

\footnotetext{
* Bu çalışma, 10-12 Mayıs 2017 tarihlerinde Antalya'da düzenlenen 9'uncu Uluslararası Eğitimde Yeni Yönelimler Kongresi’nde bildiri olarak sunulmuştur.

** Sorumlu yazar/Corresponding author.

e-posta: y.adanir@alparslan.edu.tr
} 
Ekici, 2010). Helvacı (2010), bilgi ve teknolojideki bu hızlı gelişmelerin, ülkelerin eğitim alanındaki amaçlarının, programlarının, öğrencilerinin, yöneticilerinin, binalarının, araç-gereçlerinin, yazılım ve donanımlarının ve mevzuatının yeniden değerlendirilmesini zorunlu kıldığını söylemektedir.

Teknolojideki hızlı gelişmelerin bütün toplumları bilgi yoğun bir yaşama doğru sürüklediğini ifade eden İşman (2011) ise, eğitim programları, eğitime yapılan yatırımlar ve eğitim politikalarının bilgi yoğun hale getirildiğini belirtmekte ve bilim adamları da dâhil olmak üzere toplumun tüm kesimlerinin 21. yüzyılın bilgi çağı olduğu noktasında birleştiğini söylemektedir. Al ve Madran'a (2004) göre ise, bilgiler artık daha fazla kişiye ulaşmakta, elde edilen bilgiler yaygınlık kazanmakta ve öğrenme-öğretme aktiviteleri artık bir ayrıcalık olmaktan ziyade tüm kesimlere ulaşmaktadır.

Bilgi çağı olarak adlandırılan bu yüzyılın, eğitim alanında önemli imkânlar sunduğunu belirten Demir (2014), bu imkânların en başında da bilişim ağı ve ağ toplumu olmanın gerekliliklerini yerine getiren ve alternatif öğrenme süreci olarak ortaya çıkan "uzaktan eğitim" in geldiğini söylemektedir.

\subsection{Uzaktan Eğitim Nedir?}

Uzaktan eğitim veya uzaktan öğrenme, fiziksel olarak sınıf ortamında bulunmayan öğrencilere öğrenme sağlamayı planlayan ve bilgi teknolojisine dayalı olan bir öğretim sistemidir. Öğretmen ve öğrencilerin aynı yerde olmadan etkileşimde bulunmalarına olanak tanıyan uzaktan eğitim, yeni teknolojiler sayesinde hem kurumlar hem de öğrenciler için gittikçe popüler bir seçenek haline gelmiştir.

Keegan (1996), uzaktan eğitimi temel olarak öğretmenin ve öğrencinin birbirlerinden farklı ortamlarda bulundukları ve okullara, üniversitelere devam etmekten ziyade evlerinde ve bazen de işyerlerinde derslere katılmayı tercih edenler için geliştirilmiş bir eğitim sistemi olarak tanımlarken, Verduin ve Clark (1989) ise uzaktan eğitimi, eğitimci ve öğrenen kişinin birbirlerinden fiziksel olarak ayrı olduğu durumlarda herhangi bir resmi öğrenme yolu olarak tanımlamıştır.

Orhan (2017), uzaktan eğitimin öğretici ve öğrenenin büyük ölçüde fiziksel olarak ayrı mekânlarda olması sebebiyle öğretim ve öğrenimin basılı materyaller ve gerektiğinde öğrencinin soru bile sorabileceği çift yönlü bir iletişim kurma imkânı sağlayan teknolojik ortamlar sayesinde sürdürüldüğü bir eğitim olduğunu söylerken, Farooq, Asmari ve Javid (2012), uzaktan eğitimde çevrimiçi desteğin etkin kullanımının İngilizce eğitim programlarının kalitesini artırabileceğini belirtmektedirler.

\subsection{Uzaktan Eğitimi Geleneksel Eğitimden Ayıran Temel Özellikler}

Uzaktan eğitimi geleneksel eğitimden ayıran bazı temel özellikler bulunmaktadır. Bu özelikler aşağıda belirtilen boyutlarda ele alınabilir (Uzaktan Eğitim, 2014):

(i) Öğretim sürecinin çoğunluğunda öğretmen ve öğrencinin coğrafi açıdan ayrı mekanlarda bulunması

(ii) Öğretmen ve öğrenciyi birleştirecek ve ders içeriğini iletecek eğitim medyasının kullanımı

(iii) Öğreten ve öğrenen arasında iki yönlü iletişimin sağlanması (iv) Eğitim ortamının eğitmen, öğrenci ve ders içeriğini bir araya getirmek için kullanılması

(v) Mekan ve zamandan bağımsızlığın sağlanması

(vi) Öğrencinin öğreticinin etkisi altında olmaksızın kendi istemi ile öğrenmesi

(vii) Kişiye göre esnek ders sürelerinin söz konusu olması

(viii) Eğitimi alacak olan bireylerin bu eğitimlerini eşzamanlı (senkron) ve eşzamanlı olmayan (asenkron) şekillerde alabilmeleri

(ix) Uzaktan eğitim sisteminin sürekli eğitim olanağ1 sağlamada etkili bir araç olması

\subsection{Türkiye'deki Yükseköğretim Kurumlarında Uzaktan Eğitim}

Özellikle bilgi ve iletişim alanındaki teknolojik gelişmeler eğitim alanında kendini hissettirmeye başlamış ve bunun bir sonucu olarak, teknoloji destekli eğitim uygulamalarının yanı sıra tamamen uzaktan verilen dersler de yaygınlık kazanmıştır. Ülkemiz de bu gelişmelere ayak uydurmuş ve farklı eğitim kademelerinde bu teknolojilerden yoğun bir şekilde faydalanılmaya başlanmıştır. Özellikle üniversiteler bu değişim ve gelişim sürecine çok çabuk adapte olmuş ve normal öğretimin yanı sıra uzaktan öğretim de yaygınlık kazanmaya başlamıştır.

Yükseköğretim Kurulu tarafindan 01.02.2013 tarihinde kabul edilen "Yükseköğretim Kurumlarında Uzaktan Öğretime İlişkin Usul Ve Esaslar”'1n 5.maddesine göre;

Yükseköğretim kurumlarının; ön lisans, lisans ve yüksek lisans düzeyinde diploma programları ile senatoları tarafından uygun görülmesi halinde, birinci ve ikinci öğretim programlarındaki bazı dersleri uzaktan ögretim yoluyla verilebilir. Uzaktan ögrretim programları ile uzaktan öğretim yoluyla verilmesi uygun görülen dersler, ağ üzerinden eşzamanlı olarak çevrimiçi teknolojilerle verilir. Derslerin yürütülmesinde kitap, radyo, televizyon, ses ve görüntü diskleri (CD/DVD) vb. çevrimdışı teknolojilerden de yararlanılabilir. Öğretim, yüz yüze ders ve uygulamalarla da desteklenebilir (YÖK, 2013).

Alınan bu kararlar doğrultusunda, Türkiye'de yükseköğretim düzeyinde tüm fakülte ve programlarda verilen zorunlu ortak dersler olan Türk Dili, Atatürk İlke ve İnkılâpları Tarihi ve Yabancı Dil dersleri uzaktan öğretim ile verilen derslere örnek olarak gösterilebilir. Bugün birçok yükseköğretim kurumunda bu dersler uzaktan eğitim yoluyla verilmektedir.

\subsection{Muş Alparslan Üniversitesinde Uzaktan Eğitim İngilizce Dersi}

Muş Alparslan Üniversitesi genelindeki bütün bölümlerde zorunlu olan ortak zorunlu yabancı dil dersleri, Rektörlük bünyesinde görevlendirmesi olan İngilizce okutmanları tarafından yürütülmektedir. Muş Alparslan Üniversitesi Lisans ve Ön Lisans Eğitim-Öğretim ve Sinav Yönetmeliği’ne göre yılda bir kez eğitim-öğretim yılının başında, ortak zorunlu yabancı dil dersinden muaf olmaları için öğrencilere resmi bir komisyon tarafindan muafiyet sınavı yapılmaktadır. Bu sınavda başarılı olan öğrenciler Yabancı Dil 1-2 derslerinden muaf tutulurlar. Başarısız olan öğrenciler ise, zorunlu ortak yabancı dil dersini iki dönem halinde almaktadırlar. $\mathrm{Bu}$ sınavın uygulamasına ilişkin esaslar Senato tarafindan belirlenir. 
24 Ağustos 2015 tarih ve 29455 sayılı resmi gazetede yayınlanan Muş Alparslan Üniversitesi Uzaktan Eğitim Uygulama Ve Araştırma Merkezi Yönetmeliği çerçevesinde kurulan Uzaktan Eğitim Uygulama ve Araştırma Merkezi (UZEM) öğrencilerin eğitim-öğretim sürecini, zaman ve mekandan bağımsız bir șekilde yürütebilmelerini desteklemek amacıyla 2015-2016 eğitim-öğretim yılında eğitim öğretim faaliyetlerine başlamıştır. Bu çerçevede Muş Alparslan Üniversitesinde Yabanc1 Dil I ve Yabancı Dil II dersleri 2015-2016 eğitim-öğretim yılı güz dönemi itibariyle uzaktan eğitim yoluyla verilmeye başlanmıştır.

Yabanc1 Dil I-II dersleri asenkron olarak dört İngilizce okutmanı tarafından yürütülmektedir. Öğrenciler, dersin öğretim elemanları tarafından sisteme yüklenen ders materyallerini, videoları ve testleri haftalık olarak internet aracılığıyla takip etmek zorundadırlar. Öğrencilerin bunları takip edip etmediği ise ilgili öğretim elemanı tarafından kontrol edilmektedir. Uzaktan Eğitim Uygulama ve Araştırma Merkezi tarafından duyurulan saatlerde ise öğrenciler dersin öğretim elemanlarıyla yüz yüze veya uzaktan eğitim sistemini kullanarak görüşebilmektedirler. Derslere devam ise, haftalık ders öğretim materyalleri ve konu sonu test aktivitelerinin öğrenciler tarafindan tamamlanması şeklinde takip edilmektedir. Değerlendirme aşamasında ise bir ara sınav ve bir final sınavı yapılmaktadır. Ara sınavlar UZEM sistemine giriş yapılıp online olarak yapılırken, final sınavları ise ilgili fakülte veya yüksekokul sorumluluğunda, öğretim elemanı eşliğinde, sınıf ortamında ve merkezi olarak gerçekleştirilmektedir. Ara sınavların yılsonu başarı puanına etkisi $\% 40$, final sınavlarının etkisi ise $\% 60$ 'tır.

\subsection{Araştırmanın Problemi}

Günümüzde, ülkemizdeki birçok üniversite bazı dersleri uzaktan eğitim sistemiyle vermektedir. Bunun için de hemen hemen her üniversite uzaktan öğretim müfredatına yönelik yönergeler hazırlayıp bunları uygulamaya koymuştur. Bu programlar daha çok yüz yüze eğitimin desteklemesi amacına yöneliktir. $\mathrm{Bu}$ yüzden uzaktan eğitim yoluyla yürütülen bu öğrenme-öğretme faaliyetlerinin izlenmesi, desteklenmesi ve geliștirilmesi gerekmektedir. Bu doğrultuda bu araştırmanın problemi, Doğu Anadolu Bölgesinde bulunan bir devlet üniversitesinde öğrencilerin uzaktan eğitim ile verilen yabancı dil (İngilizce) dersi ile ilgili görüşlerini araştırmaktır.

\subsection{Araştırmanın Amacı}

$\mathrm{Bu}$ araştırmanın amacı uzaktan eğitim ile verilen İngilizce dersine yönelik öğrenci görüşlerini incelemektir. Bu temel amaç çerçevesinde aşağıdaki sorulara yanıt aranmıştır:

(i) Öğrencilerin uzaktan eğitim ile verilen İngilizce dersine yönelik görüşlerinin dağılımı nasıldır?

(ii) Araştırmaya katılan öğrencilerin uzaktan eğitim ile verilen İngilizce dersine yönelik görüşleri; cinsiyet, öğrenim, dersi alma, kendilerine ait bilgisayarlara sahip olma, ücretsiz internet erişimine sahip olma ve birinci dönem not ortalaması durumlarına göre istatistiksel olarak anlamlı bir farklılık göstermekte midir?

\section{Yöntem}

\subsection{Araştırma Modeli}

$\mathrm{Bu}$ araştırmada, Uzaktan Eğitim İngilizce Dersi Öğretim Programının öğrenci görüşlerine göre farklı değişkenler açısından incelenmesi amaciyla, tarama modellerinden ilişkisel tarama modeli kullanılmıştır. İlişkisel tarama modeli, iki ya da daha çok sayıdaki değişken arasında birlikte değişimin varlığını ve derecesini belirlemeyi amaçlayan araştırma modelidir (Karasar, 2016). Aynı zamanda araştırma, üniversite öğrencilerinin uzaktan eğitim ile verilen İngilizce dersi hakkındaki görüşlerinin cinsiyet, öğrenim, dersi alma, kendilerine ait bilgisayarlara sahip olma, ücretsiz internet erişimine sahip olma ve birinci dönem not ortalaması durumlarına göre farklılaşıp farklılaşmadığını incelemek amacıyla yapıldığı için nedensel karşılaştırma modelini içermektedir. Nedensel karşılaştırma araştırma modeli, araştırma kapsamına giren katılımcılara ait farklılıkların nedenlerini veya sonuçlarını koşullara müdahale etmeksizin incelemeyi hedefler (Büyüköztürk, Kılıç Çakmak, Akgün, Karadeniz ve Demirel, 2016).

\subsection{Evren ve Örneklem}

Araştırmanın evrenini 2016-2017 akademik yılının güz döneminde Muş Alparslan Üniversitesinin 10 fakülte/yüksekokulunda uzaktan eğitim teknolojileri yoluyla verilen "İngilizce" dersini alan 2411 öğrenci oluşturmaktadır. Tüm evrene ulaşmanın zor olduğu durumlarda bütün evren üzerine çalışmak yerine ilgili evreni temsil yüzdesi yüksek olan bir örneklem seçip çalışmaya bu örneklem üzerinden devam etmek araştırmacılara büyük kolaylık sağlar (Ural ve Kılıç, 2010). Evrende bulunan öğrencilerin fakülte/yüksekokullara göre sayılarının üniversitenin web sayfasında yayınlanan listeden tespit edilmesinden sonra temsil yüzdesini yüksek tutmak için evrenin yaklaşık \%20'sine ulaşılması hedeflenmiştir. Evreni oluşturan öğrenci listelerinin alınması durumunda, doğrudan tabakalara ayırma ve her bir tabakadan ağırlığı oranında örneklem alma evrende bulunan homojen alt grupların örneklemde temsilliğini garanti altına alır (Büyüköztürk vd., 2016). Bu sebeple oranlı tabakalı örnekleme yöntemi kullanılarak fakülte/yüksekokullarda uygulanmak üzere çalışmamız için evrenin (n:2411) \%20'sine denk gelen 480 adet ölçek kullanılmıştır. Araştırmacının evrenini ve evreninin alt tabakalarını saptadıktan sonra, her tabaka içinden seçkisiz örnekleme yöntemini kullanarak örneklemini oluşturabileceğini belirten Yıldırım ve Şimşek (2016), önemli olanın evren içindeki alt tabakaların varlığından yola çıkarak evren üzerinde çalışmak olduğunu belirtmektedirler. Can (2017) ise, evrenden seçilen katmanların büyüklüklerinin farklı olması durumunda, alt evrenlerden örnekleme alınacakların, her bir alt evrenin evren içindeki oranı dâhilinde belirleneceğini belirtmektedir. Dağıtılan ölçeklerden 450 tanesi geri toplanmıştır ve geri toplanan ölçeklerden 30 tanesi kişisel bilgilerdeki eksikliklerden veyahut tüm sorulara aynı yanıtların verilmesinden dolayı elenmiştir. İşleme konan 420 ölçek evrenin yaklaşık \%17'sini temsil etmektedir. Tabakalı örnekleme yöntemiyle oluşturulan örneklemde bulunan öğrencilerin (n:420) fakülte/yüksekokullara göre sayıları ve temsil yüzdeleri Tablo 1'de gösterilmektedir. 
Tablo 1. Fakülte ve Yüksekokullara Göre Evrende Bulunan Öğrenci Sayısı ve Yüzdesi ile Örneklemde Bulunan Öğrenci Sayısı ve Yüzdesi

\begin{tabular}{lcccc}
\hline & \multicolumn{2}{c}{ Evren } & \multicolumn{2}{c}{ Örneklem } \\
\hline \multicolumn{1}{c}{ Fakülte/Yüksekokul } & $\mathrm{f}$ & $\%$ & $\mathrm{f}$ & $\%$ \\
\hline Eğitim Fakültesi & 311 & 12,9 & 59 & 14,0 \\
Fen Edebiyat Fakültesi & 343 & 14,2 & 57 & 13,6 \\
Mühendislik Mimarlık Fakültesi & 57 & 2,3 & 7 & 1,7 \\
İslami İlimler Fakültesi & 246 & 10,2 & 45 & 10,7 \\
İktisadi İdari Bilimler Fakültesi & 249 & 10,3 & 42 & 10,0 \\
Sağlık Yüksekokulu & 153 & 6,3 & 23 & 5,5 \\
Sosyal Bilimler Meslek & 323 & 13,5 & 62 & 14,8 \\
Yüksekokulu & & & & \\
Teknik Bilimler Meslek & 513 & 21,3 & 87 & 20,7 \\
Yüksekokulu & 135 & 5,6 & 24 & 5,7 \\
Malazgirt Meslek Yüksekokulu & & & \\
Sağlik Hizmetleri Meslek & 81 & 3,4 & 14 & 3,3 \\
Yüksekokulu & 2411 & 100 & 420 & 100 \\
\hline Toplam & & & & \\
\hline
\end{tabular}

Katılımcıların demografik bulgularına ilişkin bilgiler ise Tablo 2'de verilmiştir.

Tablo 2. Demografik Bulgulara İlişkin Bilgiler

\begin{tabular}{llcc}
\hline Demografik Bilgiler & & $\mathrm{n}$ & $\mathbf{\%}$ \\
\hline \multirow{2}{*}{ Cinsiyet } & Kadın & 230 & 54,8 \\
\cline { 2 - 4 } & Erkek & 190 & 45,2 \\
\hline \multirow{2}{*}{ Öğrenim Türü } & Lisans & 233 & 55,5 \\
\cline { 2 - 4 } & Ön Lisans & 187 & 44,5 \\
\hline \multirow{2}{*}{ Dersi Alma Durumu } & İlk Defa & 330 & 78,6 \\
\cline { 2 - 4 } & İki defa ve + & 90 & 21,4 \\
\hline Bilgisayara Sahip Olma & Sahip & 112 & 26,7 \\
\cline { 2 - 4 } Durumu & Sahip Değil & 308 & 73,3 \\
\hline \multirow{2}{*}{ Ücretsiz İnternet Erişimi } & Evet & 251 & 59,8 \\
\cline { 2 - 4 } & Hayır & 169 & 40,2 \\
\hline \multirow{3}{*}{ Birinci Dönem Notu } & $0-44$ & 131 & 31,2 \\
\cline { 2 - 4 } & $45-57$ & 124 & 29,5 \\
\cline { 2 - 4 } & $58-72$ & 102 & 24,3 \\
\cline { 2 - 4 } & $73-86$ & 23 & 9,5 \\
\cline { 2 - 4 } & $87-100$ & 5,5 \\
\hline
\end{tabular}

Araştırmaya katılan öğrencilerin 230 (\%54,8)'u kadın, 190 $(\% 45,2)$ ' 1 ise erkektir. Katılımcıların $330(\% 78,6)$ 'u dersi ilk defa alırken, $90(\% 21,4)$ '1 ise dersi iki defa veya üzeri sayıda almışlardır. Kendilerine ait bilgisayara sahip olma durumuna bakıldığında öğrencilerin $112(\% 26,7)$ 'si kendilerine ait bilgisayara sahipken, $308(\% 73,3)$ 'si ise kendilerine ait bilgisayara sahip değillerdir. Katılımcıların $251(\% 59,8)$ 'i kaldıkları yerde ücretsiz internet erişimine sahip olduklarını, $169(\% 40,2)$ 'u ise ücretsiz internet erişimine sahip olmadıklarını belirtmişlerdir. Katılımcıların ilk dönem notlarına bakıldığında, 131 (\%31,2)'nin 0-44 aralığında, 124 (\%29,5)'ünün 45-57 aralığında, $102(\% 24,3)$ 'sinin 58-72 aralığında, $40(\% 9,5)$ 'nın $73-86$ aralığında ve $23(\% 5,5)$ 'nün 87-100 aralığında notlara sahip oldukları görülmektedir.

\subsection{Veri Toplama Arac1}

Araştırmanın verilerini toplamak amacıyla Orhan (2016) tarafindan geliştirilen 36 maddeden oluşan beşli Likert türünde Uzaktan Eğitimle Yürütülen Yabancı Dil I (İngilizce) Dersi Öğretim Programını Değerlendirme Ölçeği (İ̈̈PDÖ) kullanılmıştır. Ölçeğin kullanılması için ölçeğin sahibinden gerekli izinler alınmıştır. Ölçek bağlam, girdi, süreç ve ürün değerlendirme olmak üzere dört boyutlu bir ölçektir. Ölçeğin bağlam boyutunda 6 , girdi boyutunda 7 , süreç boyutunda 9 ve ürün boyutunda 13 madde bulunmaktadır. Ölçeğin bağlam boyutunu 1-6. maddeler, girdi boyutunu 7-14. maddeler, süreç boyutunu 15-23. maddeler ve ürün boyutunu 24-36. maddeler oluşturmaktadır. Ayrıca genel uygulama sonucunda elde edilen verilerden Cronbach alpha güvenirlik katsayısı hem toplam puan için hem de alt boyutlar için hesaplanmış ve sonuçlar Tablo 3 'te verilmiştir. Alpar (2016) güvenirlik katsayısının 0,80-1,00 arasında olması durumunda, ölçeğin güvenirliğinin yüksek olduğunu söylemektedir. Çalışmada kullanılan ölçeğin hem toplam puanda hem de alt boyutlarda bu oranlara sahip olmasindan dolayı yüksek güvenirliğe sahip olduğu söylenebilir.

Tablo 3. Ölçekten Elde Edilen Puanlara İlişkin Güvenirlik Analizi Sonuçları

\begin{tabular}{lc}
\hline Güvenirlik Analiz & Cronbach Alpha $(\alpha)$ \\
\hline Ölçeğin Tümüne İlişkin & 0,96 \\
Bağlam Boyutu & 0,87 \\
Girdi Boyutu & 0,86 \\
Süreç Boyutu & 0,89 \\
Ürün Boyutu & 0,94 \\
\hline
\end{tabular}

Ölçeğin geliştirildiği çalışmadaki güvenirlik analizi incelendiğinde ise; ölçeğin tümüne ilişkin puanın 0,96 , bağlam boyutuna ait puanın 0,87 , girdi boyutuna ait puanın 0,90 , süreç boyutuna ait puanın 0,91 ve ürün boyutuna ait puanın 0,95 olduğu tespit edilmiştir. Dolayısıyla bu çalışma ile ölçeğin geliştirildiği çalışmadaki iç tutarlılık katsayılarının toplam puan ve bağlam boyutunda aynı çıktığı, diğer boyutlarda ise birbirine çok yakın değerler aldığı söylenebilir.

\subsection{Verilerin Analizi}

Araştırmada elde edilen veriler, kodlanarak bilgisayara yüklenilmiş ve "SPSS 17,0 for Windows" istatistik programı kullanılarak çözümlenmiştir. Örneklem gruplarının normal dağılım gösterip göstermediğini tespit etmek amacıyla, örneklem sayısı 50'den yukarı olduğu için KolmogorovSimirnov testi kullanılmıştır. Bu teste ait sonuçlar Tablo 4'te verilmiştir.

Tablo 4. Normallik Testi Sonuçları

\begin{tabular}{lc}
\hline Kolmogorov-Smirnov & Normallik \\
\hline Ölçeğin Tümüne İlişkin & 0,004 \\
Bağlam Boyutu & 0,000 \\
Girdi Boyutu & 0,001 \\
Süreç Boyutu & 0,000 \\
Ürün Boyutu & 0,000 \\
\hline
\end{tabular}

Toplam puana ve dört alt boyuta ilişkin dağılımın normal olmaması $(\mathrm{p}<0.05)$ nedeniyle verilerin analizinde parametrik olmayan testler kullanılmıştır.

İki alt gruptan oluşanlar için Mann-Whitney U Testi, ikiden fazla alt grubu olanlar için de Kruskal Wallis H Testi kullanılmıştır. Kruskal Wallis testi sonucunda istatistiksel olarak ortaya çıkan anlamlı farklılıkların hangi gruplar arasında olduğunu tespit etmek için de ikili gruplar şeklinde Mann Whitney U testi kullanılmıştır. 
Ölçekte yer alan öğrenci görüşlerinin aritmetik ortalamalarını karşılaştırırken Tablo 5'te ki puanlar kullanılmıştır.

Tablo 5. Öğrenci Görüşlerinin Aritmetik Ortalaması

\begin{tabular}{lc}
\hline Görüşler & Puanlar \\
\hline Hiç Katılmıorum & $1,00-1,79$ \\
Katılmıyorum & $1,80-2,59$ \\
Ne Katılıyorum Ne Katılmıorum & $2,60-3,39$ \\
Katılıyorum & $3,40-4,19$ \\
Tamamen Katılıyorum & $4,20-5,00$ \\
\hline
\end{tabular}

\section{Bulgular ve Yorumlar}

Bu bölümde "Uzaktan Eğitim ile Verilen İngilizce Dersi Öğretim Programına İlişkin Öğrenci Görüşleri” ve "Uzaktan Eğitim ile Verilen İngilizce Dersinin Çeşitli Değişkenler Açısından Değerlendirilmesi" ile ilgili bulgular ve yorumlar yer almaktadır.

\subsection{Uzaktan Eğitim ile Verilen İngilizce Dersi Hakkında Öğrenci Görüşleri}

$\mathrm{Bu}$ bölümde, araştırmaya katılan öğrencilerin uzaktan eğitimle verilen İngilizce dersinin farklı boyutlara göre değerlendirmelerine ilişkin bulgularına yer verilmiştir.

Tablo 6. Farklı Boyutlara ve Toplam Ölçeğe Ait Öğrenci Cevaplarının Ortalamaları ve Standart Sapma Değerleri

\begin{tabular}{lcc}
\hline & $\overline{\mathrm{X}}$ & ss \\
\hline Bağlam Değerlendirme & 2,25 & 0,95 \\
Girdi Değerlendirme & 2,34 & 0,83 \\
Süreç Değerlendirme & 2,78 & 0,91 \\
Ürün Değerlendirme & 2,12 & 0,92 \\
Programın Tümünü Değerlendirme & 2,36 & 0,76 \\
\hline
\end{tabular}

Tablo 6 incelendiğinde öğrenci görüşlerinin süreç değerlendirme boyutunda "ne katıllyorum ne de katılmıyorum" düzeyinde ( $\overline{\mathrm{X}}: 2,78)$ olduğu, diğer boyutlar olan bağlam $(\bar{X}: 2,25)$, girdi $(\bar{X}: 2,34)$ ve ürün $(\bar{X}: 2,12)$ değerlendirme boyutlarında ise "katılmıyorum" düzeyinde olduğu görülmektedir. Ölçeğin tamamına ait ortalamaya bakıldığında ise öğrenci görüşlerinin "katılmıyorum" düzeyinde $(\overline{\mathrm{X}}: 2,36)$ olduğu görülmektedir.

Tablo 7. Programın Bağlam Boyutuna İlişkin Görüşlerin Ortalamaları ve Standart Sapma Değerleri

\begin{tabular}{lcc}
\hline Bağlam Değerlendirme & $\overline{\mathrm{X}}$ & ss \\
\hline $\begin{array}{l}\text { 1. Programın amaçları öğrenci ihtiyaçları ile } \\
\text { uyumludur. }\end{array}$ & 2,22 & 1,27 \\
$\begin{array}{l}\text { 2. Programın amaçları öğrenci beklentileriyle } \\
\text { uyumludur. }\end{array}$ & 2,15 & 1,15 \\
$\begin{array}{l}\text { 3. Program öğrencilerin İngilizce dil } \\
\text { seviyelerine uygundur. }\end{array}$ & 2,35 & 1,29 \\
$\begin{array}{l}\text { 4. Programın süresi programın amaçlarına } \\
\text { ulaşılması çcin yeterlidir. }\end{array}$ & 2,52 & 1,23 \\
$\begin{array}{l}\text { 5. Program diğer dersleri tamamlayıcı } \\
\text { niteliktedir. }\end{array}$ & 2,22 & 1,15 \\
$\begin{array}{l}\text { 6. Uzaktan eğitimle yapılan İngilizce dersleri } \\
\text { Ingilizce bilgisini geliştirir niteliktedir. }\end{array}$ & 2,05 & 1,25 \\
\hline Toplam & 2,25 & 0,95 \\
\hline
\end{tabular}

Tablo 7'ya bakıldığında, öğrencilerin tüm maddelere "katılmıyorum" düzeyinde cevap verdikleri görülmüştür. "Uzaktan eğitimle yapılan İngilizce dersleri İngilizce bilgisini geliştirir niteliktedir" maddesine en düşük düzeyde ( $\overline{\mathrm{X}}: 2,05)$ katılım gösterildiği görülmektedir. $\mathrm{Bu}$ sonuçtan hareketle öğrencilerin bu programdan çok verim alamadıkları söylenebilir.

Tablo 8. Programın Girdi Boyutuna İlișkin Görüşlerin Ortalamaları ve Standart Sapma Değerleri

\begin{tabular}{lcc}
\hline Girdi Değerlendirme & $\overline{\mathrm{X}}$ & ss \\
\hline $\begin{array}{l}\text { 7. Portal, geliştirilmesi amaçlanan İngilizce } \\
\text { dinleme becerisi için yeterli kaynak }\end{array}$ & 2,26 & 1,44 \\
$\begin{array}{l}\text { sağlamaktadır. } \\
\text { 8. Portal, geliştirilmesi amaçlanan İngilizce }\end{array}$ & & \\
$\begin{array}{l}\text { yazma becerisi için yeterli kaynak } \\
\text { sağlamaktadır. }\end{array}$ & 2,13 & 1,02 \\
$\begin{array}{l}\text { 9. Portal, geliştirilmesi amaçlanan İngilizce } \\
\text { konuşma becerisi için yeterli kaynak }\end{array}$ & & \\
$\begin{array}{l}\text { sağlamaktadır. } \\
\text { 10. Portal, geliştirilmesi amaçlanan İngilizce } \\
\text { okuma becerisi için yeterli kaynak }\end{array}$ & 2,04 & 1,07 \\
$\begin{array}{l}\text { sağlamaktadır. } \\
\text { 11. Portal, geliştirilmesi amaçlanan İngilizce } \\
\text { dilbilgisi için yeterli kaynak sağlamaktadır. }\end{array}$ & 2,10 & 1,06 \\
$\begin{array}{l}\text { 12. Portalda kullanılan öğrenme kaynakları / } \\
\text { materyalleri kalitelidir. }\end{array}$ & 2,48 & 1,11 \\
$\begin{array}{l}\text { 13. Sunulan ders içeriği niteliklidir. } \\
\text { 14. Portala yüklenen testlerin sayısı yeterlidir. }\end{array}$ & 2,77 & 1,17 \\
\hline Toplam & 2,34 & 0,83 \\
\hline
\end{tabular}

Tablo 8'ye bakıldığında, 7-8-9-10-11 ve 12.maddelere "Katılmıyorum" düzeyinde cevaplar verildiği, 13.madde olan "Sunulan ders içeriği niteliklidir" ve 14. madde olan "Portala yüklenen testlerin sayısı yeterlidir" maddelerine ise "Ne Katıliyorum ne de Katılmıyorum" şeklinde cevaplar verildiği görülmektedir ( $\overline{\mathrm{X}}: 2,77$ ve $\overline{\mathrm{X}}: 2,67)$. Bu sonuçlardan hareketle, portalın İngilizcenin dört temel becerisi olan konuşma, yazma, okuma ve dinleme becerilerini geliştirmede yetersiz kaldığı söylenebilir.

Tablo 9. Programın Süreç Boyutuna İlişkin Görüşlerin Ortalamaları ve Standart Sapma Değerleri

\begin{tabular}{lcc}
\hline Süreç Değerlendirme & $\bar{X}$ & ss \\
\hline $\begin{array}{l}\text { 15. Ögretim elemanına rahatça soru } \\
\text { sorulabilmektedir. }\end{array}$ & 2,97 & 1,35 \\
$\begin{array}{l}\text { 16. Öğretim elemanları konunun öğrenilmesi } \\
\text { için kolaylaştırıcı yollar denemektedirler. }\end{array}$ & 2,74 & 1,22 \\
$\begin{array}{l}\text { 17. Öğretim elemanları programı amacına } \\
\text { uygun şekilde uygulamaktadırlar. }\end{array}$ & 2,92 & 1,21 \\
$\begin{array}{l}\text { 18. Ögretim elemanları konuya/amaca uygun } \\
\text { ögretim yöntemlerini kullanmaktadırlar. }\end{array}$ & 2,78 & 1,21 \\
$\begin{array}{l}\text { 19. Öğretim elemanları materyalleri etkili } \\
\text { kullanmaktadırlar. }\end{array}$ & 2,64 & 1,15 \\
$\begin{array}{l}\text { 20. Program uygulanırken bir aksaklık } \\
\text { yaşandığında çözümlenmesi için çaba } \\
\text { harcanmaktadır. }\end{array}$ & 2,76 & 1,30 \\
$\begin{array}{l}\text { 21. Portalda sunulan ders materyalleri ve } \\
\text { testler konuyu pekiştirici bir şekilde } \\
\text { kullanılmaktadır. }\end{array}$ & 2,58 & 1,20 \\
$\begin{array}{l}\text { 22. Program süresince sınavlar sorunsuz bir } \\
\text { şekilde uygulanmaktadır. }\end{array}$ & 2,83 & 1,31 \\
$\begin{array}{l}\text { 23. Portalda sunulan videolarda öğretim } \\
\text { elemanı konuyu açık ve net bir şekilde } \\
\text { anlatmaktadır. }\end{array}$ & 2,85 & 1,23 \\
\hline \begin{tabular}{l} 
Toplam \\
\hline
\end{tabular} & 2,78 & 0,91 \\
\hline
\end{tabular}


Tablo 9'a bakıldığında, öğrencilerin "Portalda sunulan ders materyalleri ve testler konuyu pekiştirici bir şekilde kullanılmaktadır" şeklindeki 21.maddeye "Katılmıyorum" düzeyinde $(\overline{\mathrm{X}}: 2,58) \quad$ cevaplar verdikleri, diğer tüm maddelere ise "Ne Kat1liyorum ne de Katılmiyorum" düzeyinde cevaplar verdikleri görülmektedir. Süreç boyutunda öğrenciler "Öğretim elemanına rahatça soru sorulabilmektedir" maddesine $(\overline{\mathrm{X}}: 2,97)$ diğer maddelerden daha olumlu görüş belirtmektedirler.

Tablo 10. Programın Ürün Boyutuna İlişkin Görüşlerinin Ortalamaları ve Standart Sapma Değerleri

\begin{tabular}{|c|c|c|}
\hline Ürün Değerlendirme & $\overline{\mathrm{X}}$ & ss \\
\hline $\begin{array}{l}\text { 24. Program sonunda öğrenciler } \\
\text { bölümlerinde amaçlanan İngilizce } \\
\text { seviyesine ulaşmaktadırlar. }\end{array}$ & 2,03 & 1,16 \\
\hline $\begin{array}{l}\text { 25. Program uzaktan öğrenme becerilerini } \\
\text { geliştirmiştir. }\end{array}$ & 2,23 & 1,20 \\
\hline $\begin{array}{l}\text { 26. Program sonunda, kelime öğrenme } \\
\text { stratejilerini geliștirmiștir. }\end{array}$ & 2,20 & 1,18 \\
\hline $\begin{array}{l}\text { 27. Bence program hedeflerine ulaşmıştır. } \\
\text { 28. Program karşılaşılan metinlerde }\end{array}$ & 2,04 & 1,18 \\
\hline $\begin{array}{l}\text { bilinmeyen kelimeleri tahmin etme } \\
\text { becerisini geliştirir niteliktedir. }\end{array}$ & 2,27 & 1,16 \\
\hline $\begin{array}{l}\text { 29. Bu programa devam etmiş olmaktan } \\
\text { memnunum. }\end{array}$ & 2,16 & 1,25 \\
\hline $\begin{array}{l}\text { 30. Program kelimeleri hafizada tutma } \\
\text { stratejilerini geliştirmiştir. }\end{array}$ & 2,13 & 1,17 \\
\hline $\begin{array}{l}\text { 31. Program sonunda metinleri okuyup } \\
\text { anlama yeteneğini geliştirmiştir. }\end{array}$ & 2,23 & 1,20 \\
\hline $\begin{array}{l}\text { 32. Program sonunda ögrenciler kendilerini } \\
\text { İngilizce yazarak ifade edebilecek seviyeye } \\
\text { ulaşmışlardır. }\end{array}$ & 1,98 & 1,15 \\
\hline $\begin{array}{l}\text { 33. Program sonunda öğrenciler } \\
\text { gerektiğinde uygun kelimeyi kullanma } \\
\text { stratejilerini uygulayacak seviyeye } \\
\text { ulaşmışlardır. }\end{array}$ & 2,10 & 1,17 \\
\hline $\begin{array}{l}\text { 34. Program sonunda öğrencilerin İngilizce } \\
\text { iletişim kurma becerisi geliştirmiştir. }\end{array}$ & 2,10 & 1,20 \\
\hline 35. Program İngilizceye ilgiyi arttırmıştır. & 2,04 & 1,18 \\
\hline $\begin{array}{l}\text { 36. Programın bana fayda sağladığını } \\
\text { düşünüyorum. }\end{array}$ & 2,15 & 1,31 \\
\hline Toplam & 2,13 & 0,92 \\
\hline
\end{tabular}

Tablo 10'a bakıldığında, öğrencilerin tüm maddelere "katılmıyorum" düzeyinde cevap verdikleri görülmüştür. "Program sonunda öğrenciler kendilerini İngilizce yazarak ifade edebilecek seviyeye ulaşmışlardır" maddesinin en düşük düzeyde $(\overline{\mathrm{X}}: 1,98)$ kaldığı görülmektedir. Öğrencilerden programdan yeteri verimi alamadıkları çıkarımında bulunulabilir.

\subsection{Uzaktan Eğitim ile Verilen İngilizce Dersi} Öğretim Programının Çeşitli Değişkenler Açısından Değerlendirilmesi

$\mathrm{Bu}$ bölümde, araștırmaya katılan öğrencilerin uzaktan eğitimle verilen İngilizce dersinin farklı değişkenlere göre değerlendirmelerine ilişkin bulgularına yer verilmiştir.

Tablo 11'de ki öğrencilerin uzaktan eğitimle yürütülen Yabancı Dil I dersi öğretim programı hakkındaki görüşlerinin cinsiyete göre farklılaşıp farklılaşmadığını belirlemek amaciyla yapilan Mann Whitney U Testi sonucunda, aradaki farkın girdi boyutunda anlamlı olduğu bulunmuştur $(\mathrm{U}=19258,00 ; \mathrm{p}=0,04)$. Girdi boyutunda erkeklerin kadınlardan daha olumlu bir görüşe sahip oldukları görülmüştür. Bağlam, süreç ve ürün boyutunda ise anlamlı bir fark bulunamamıştır.

Tablo 11. Öğrencilerin Program Hakkındaki Görüşlerinin Cinsiyet Değişkenine Göre Mann Whitney U Testi Sonuçları

\begin{tabular}{lcccccc}
\hline $\begin{array}{l}\text { Alt } \\
\text { Boyutlar }\end{array}$ & Cinsiyet & $\mathrm{N}$ & $\begin{array}{c}\text { Sira } \\
\text { Ort. }\end{array}$ & $\begin{array}{c}\text { Sira } \\
\text { Toplamı }\end{array}$ & $\mathrm{U}$ & $\mathrm{p}$ \\
\hline \multirow{2}{*}{ Bağlam } & Kadın & 230 & 205,11 & 47174,50 & 20609,5 & 0,32 \\
& Erkek & 190 & 217,03 & 41235,50 & & \\
\hline \multirow{2}{*}{ Girdi } & Kadın & 230 & 199,23 & 45823,00 & 19258,0 & 0,04 \\
& Erkek & 190 & 224,14 & 42587,00 & & \\
\hline \multirow{2}{*}{ Süreç } & Kadın & 230 & 213,69 & 49148,00 & 21117,0 & 0,55 \\
& Erkek & 190 & 206,64 & 39262,00 & & \\
\multirow{2}{*}{ Ürün } & Kadın & 230 & 202,88 & 46662,50 & 20097,5 & 0,16 \\
& Erkek & 190 & 219,72 & 41747,50 & & \\
\hline
\end{tabular}

Dolayısıyla cinsiyetin öğrencilerin program hakkındaki görüşlerini girdi boyutunda etkileyen bir faktör olduğu görülmektedir. Fakat diğer boyutlar olan bağlam, süreç ve ürün boyutlarında ise cinsiyetin ögrrencilerin program hakkındaki görüşlerini etkileyen bir faktör olmadığı görülmüştür.

Tablo 12'de ki öğrencilerin Yabancı Dil I dersi öğretim programı hakkındaki görüşlerinin öğrenim durumlarına göre farklılaşıp farklılaşmadığını belirlemek amacıyla yapılan Mann Whitney U Testi sonucunda aradaki farkın süreç boyutunda anlamlı olduğu bulunmuştur ( $U=18818,50$; $\mathrm{p}=0,01)$. Süreç boyutunda lisans öğrencileri ön lisans öğrencilerine göre daha olumlu görüşlere sahiptirler. Dolayısıyla öğrencilerin öğrenim durumları uzaktan eğitimle yürütülen Yabancı Dil I dersi öğretim programı hakkındaki görüşleri üzerinde süreç boyutunda anlamlı bir farklılığa sahiptir, fakat bağlam, girdi ve ürün boyutlarında anlamlı bir farklılığa sahip değildir.

Öğrencilerin Yabanc1 Dil I dersi öğretim programı hakkındaki görüşlerinin dersi alma durumlarına göre farklılaşıp farklılaşmadığını belirlemek amacıyla yapılan Mann Whitney U Testi sonucunda aradaki farkın hiçbir boyutta anlamlı olmadığı bulunmuştur (Tablo 13). Dolayısıyla öğrencilerin uzaktan eğitimle yürütülen Yabancı Dil I dersi öğretim programı hakkındaki görüşleri dersi kaç kez aldıkları durumuna göre farklılaşmamaktadır.

Tablo 14'te ise öğrencilerin uzaktan eğitimle yürütülen Yabancı Dil I dersi öğretim programı hakkındaki görüşlerinin kendilerine ait bilgisayara sahip olma durumuna göre farklılaşıp farklılaşmadığını belirlemek amacıyla yapılan Mann Whitney U Testi sonucunda aradaki farkın hiçbir boyutta anlamlı olmadığı bulunmuştur. Dolayısıyla kendilerine ait bilgisayara sahip olma durumunun öğrencilerin program hakkındaki görüşlerini etkileyen bir faktör olmadığı görülmektedir.

Tablo 15'de ki öğrencilerin uzaktan eğitimle yürütülen Yabancı Dil I dersi öğretim programı hakkındaki görüşlerinin ikamet edilen yerde ücretsiz internet erişimi durumuna göre farklılaşıp farklılaşmadığını belirlemek amacıyla yapılan Mann Whitney U Testi sonucunda aradaki farkın süreç boyutunda anlamlı olduğu bulunmuştur $(\mathrm{U}=18783,00 ; \mathrm{p}=0,04)$. Süreç boyutunda ücretsiz internet erişimine sahip olanların, ücretsiz internet erişimine sahip olmayanlara göre daha olumlu bir görüşe sahip oldukları görülmüştür. Bağlam, girdi ve ürün boyutunda ise anlamlı bir fark bulunamamıştır. 
Tablo 12. Öğrencilerin Programa İlişkin Görüşlerinin Lisans ve Ön Lisans Değişkenine Göre Mann Whitney U Testi Sonuçları

\begin{tabular}{llccccc}
\hline Alt Boyutlar & Öğrenim & N & Sira Ort. & Sira Toplam & U & p \\
\hline \multirow{2}{*}{ Bağlam } & Lisans & 208 & 211,3 & 43958,0 & 21874,0 & 0,89 \\
& Ön Lisans & 212 & 209,6 & 44452,0 & & \\
& Lisans & 208 & 217,4 & 45229,0 & 20603,0 & 0,25 \\
\multirow{2}{*}{ Girdi } & Ön Lisans & 212 & 203,6 & 43181,0 & & \multirow{2}{*}{0,01} \\
& Lisans & 208 & 226,0 & 47013,5 & 18818,5 & \\
\multirow{2}{*}{ Süreç } & Ön Lisans & 212 & 195,2 & 41396,5 & & \multirow{2}{*}{0,98} \\
\multirow{2}{*}{ Ürün } & Lisans & 208 & 210,3 & 43752,5 & & \\
& Ön Lisans & 212 & 210,6 & 44657,5 & & \\
\hline
\end{tabular}

Tablo 13. Öğrencilerin Programa İlişkin Görüşlerinin Dersi Alma Değişkenine Göre Mann Whitney U Testi Sonuçları

\begin{tabular}{llccccc}
\hline Alt Boyutlar & Öğrenim & $\mathrm{N}$ & Sira Ort. & Sira Toplam1 & $\mathrm{U}$ & $\mathrm{p}$ \\
\hline \multirow{3}{*}{ Bağlam } & İlk Defa & 330 & 208,68 & 68865,50 & 14250,50 & 0,56 \\
\hline \multirow{3}{*}{ Girdi } & İki ve Üzeri & 90 & 217,16 & 19544,50 & & \multirow{2}{*}{0,21} \\
\hline \multirow{3}{*}{ Süreç } & İlk Defa & 330 & 206,64 & 68190,50 & 13575,50 & \\
\hline \multirow{2}{*}{ Ürün } & İki ve Üzeri & 90 & 224,66 & 20219,50 & & 0,39 \\
& İlk Defa & 330 & 213,18 & 70350,50 & 13964,50 & \\
\hline
\end{tabular}

Tablo 14. Öğrencilerin Program Hakkındaki Görüşlerinin Bilgisayara Sahip Olma Değişkenine Göre Mann Whitney U Testi Sonuçları

\begin{tabular}{llccccc}
\hline Alt Boyutlar & Bilgisayar & $\mathrm{N}$ & Sira Ort. & Sira Toplam1 & $\mathrm{U}$ & $\mathrm{p}$ \\
\hline \multirow{2}{*}{ Bağlam } & Evet & 112 & 218,26 & 24445,00 & 16379,00 & 0,43 \\
& Hayır & 308 & 207,68 & 63965,00 & & \\
& Evet & 112 & 213,99 & 23967,00 & 16857,00 & 0,72 \\
\multirow{2}{*}{ Girdi } & Hayır & 308 & 209,23 & 64443,00 & & 0,91 \\
& Evet & 112 & 209,44 & 23457,50 & 17129,50 & \\
\multirow{2}{*}{ Süreç } & Hayır & 308 & 210,88 & 64952,50 & & \multirow{2}{*}{0,17} \\
\multirow{2}{*}{ Ürün } & Evet & 112 & 224,08 & 25097,50 & 6,50 & \\
& Hayır & 308 & 205,56 & 63312,50 & & \\
\end{tabular}

Tablo 15. Öğrencilerin Program Hakkındaki Görüşlerinin Ücretsiz İnternet Erişimi Değişkenine Göre Mann Whitney U Testi Sonuçları

\begin{tabular}{llccccc}
\hline Alt Boyutlar & Bilgisayar & N & Sira Ort. & Sira Toplam1 & U & p \\
\hline \multirow{3}{*}{ Bağlam } & Evet & 251 & 213,10 & 53488,50 & 20556,50 & 0,60 \\
\hline \multirow{3}{*}{ Girdi } & Hayır & 169 & 206,64 & 34921,50 & & 0,26 \\
\hline \multirow{3}{*}{ Süreç } & Evet & 251 & 216,02 & 54220,50 & 19824,50 & \\
\hline \multirow{3}{*}{ Ürün } & Hayır & 169 & 202,30 & 34189,50 & & 0,04 \\
\hline
\end{tabular}

Tablo 16. Öğrencilerin Programa İlişkin Görüşlerinin 1.Dönem Aldıkları Not Değişkenine Göre Kruskal Wallis Testi Sonuçları

\begin{tabular}{|c|c|c|c|c|c|c|c|}
\hline Alt Boyutlar & Not & $\mathrm{n}$ & Sira Ort. & $\mathrm{X}^{2}$ & $\mathrm{sd}$ & $\mathrm{p}$ & Anlamlı Fark \\
\hline \multirow{5}{*}{ Bağlam } & $0-44$ & 131 & 178,50 & 17,660 & 4 & ,00 & A-C \\
\hline & $45-57$ & 124 & 207,88 & & & & A-D \\
\hline & $58-72$ & 102 & 237,75 & & & & A-E \\
\hline & $73-86$ & 40 & 236,38 & & & & \\
\hline & $87-100$ & 23 & 241,02 & & & & \\
\hline \multirow{5}{*}{ Girdi } & $0-44$ & 131 & 195,81 & 8,143 & 4 & 09 & \\
\hline & $45-57$ & 124 & 199,76 & & & & \\
\hline & $58-72$ & 102 & 232,68 & & & & \\
\hline & $73-86$ & 40 & 236,41 & & & & \\
\hline & $87-100$ & 23 & 208,63 & & & & \\
\hline \multirow{5}{*}{ Süreç } & $0-44$ & 131 & 176,25 & 18,684 & 4 & ,00 & $\mathrm{A}-\mathrm{C}$ \\
\hline & $45-57$ & 124 & 212,13 & & & & A-D \\
\hline & $58-72$ & 102 & 233,25 & & & & \\
\hline & $73-86$ & 40 & 249,55 & & & & \\
\hline & $87-100$ & 23 & 228,00 & & & & \\
\hline \multirow{5}{*}{ Ürün } & $0-44$ & 131 & 193,58 & 13,192 & 4 & 01 & $\mathrm{~A}-\mathrm{C}$ \\
\hline & $45-57$ & 124 & 195,04 & & & & A-E \\
\hline & $58-72$ & 102 & 228,63 & & & & B-E \\
\hline & $73-86$ & 40 & 236,99 & & & & \\
\hline & $87-100$ & 23 & 263,72 & & & & \\
\hline
\end{tabular}


Dolayısıyla ücretsiz internet erişimine sahip olma durumunun öğrencilerin program hakkındaki görüşlerini süreç boyutunda etkileyen bir faktör olduğu görülmektedir. Fakat diğer boyutlar olan bağlam, girdi ve ürün boyutlarında ise ücretsiz internet erişimine sahip olma durumunun öğrencilerin program hakkındaki görüşlerini etkileyen bir faktör olmadığı görülmüştür.

Öğrencilerin Yabancı Dil I dersi öğretim programı hakkındaki görüşlerinin 1.dönem aldıkları notlara göre farklılaşıp farklılaşmadığını belirlemek amacıyla yapılan Kruskal Wallis Testi sonucunda aradaki farkın bağlam, süreç ve ürün boyutlarında anlamlı olduğu bulunmuştur (Tablo 16). Farkın hangi ortalamalar arasında olduğunu belirlemek için gruplar arasında ikili olarak Mann Whitney U Testi kullanılmıştır.

Programın bă̆lam boyutundan elde edilen bulgulara göre, notu 0-44 arasında olan ögrencilerin program hakkındaki görüşleri ile notu 58-72 arasında olan öğrencilerin görüşleri, notu 58-72 arasında olan öğrencilerin lehine anlamlı bir şekilde farklılaştı̆ğ görülmüştür ( $U=4819,50 ; p=0,00)$. Aynı şekilde notu 0-44 arasında olan öğrencilerin program hakkındaki görüşleri ile notu 73-86 arasında olan öğrencilerin görüşleri, notu 73-86 arasında olan öğrencilerin lehine anlamlı bir şekilde farklılaştığı görülmüştür (U=1913,00; p=0,01). Ayrica notu 0-44 arasında olan öğrencilerin program hakkındaki görüşleri ile notu 87-100 arasında olan öğrencilerin görüşleri, notu 87-100 arasında olan öğrencilerin lehine anlamlı bir şekilde farklılaştığı görülmüştür ( $U=1060,50$; $\mathrm{p}=0,02)$.

Programın süreç boyutundan elde edilen bulgulara göre, notu 0-44 arasında olan ögrencilerin program hakkındaki görüşleri ile notu 58-72 arasında olan öğrencilerin görüşleri, notu 58-72 arasında olan öğrencilerin lehine anlamlı bir şekilde farklılaştığ1 görülmüştür ( $U=4857,50 ; p=0,00)$. Aynı şekilde notu 0-44 arasında olan öğrencilerin program hakkındaki görüşleri ile notu 73-86 arasında olan öğrencilerin görüşleri, notu 73-86 arasında olan öğrencilerin lehine anlamlı bir şekilde farklılaştığı görülmüştür ( $U=1743,50 ; p=0,01)$.

Programın ürün boyutundan elde edilen bulgulara göre ise, notu 0-44 arasında olan öğrencilerin program hakkındaki görüşleri ile notu 58-72 arasında olan öğrencilerin görüşleri, notu 58-72 arasında olan öğrencilerin lehine anlamlı bir şekilde farklılaştığ1 görülmüştür $(U=5530,50 ; p=0,02)$. Aynı şekilde notu 0-44 arasında olan öğrencilerin program hakkındaki görüşleri ile notu 87-100 arasında olan öğrencilerin görüşleri, notu 87-100 arasında olan öğrencilerin lehine anlamlı bir şekilde farklılaştığı görülmüştür $(\mathrm{U}=1012,50 ; \mathrm{p}=0,01)$. Ayrıca notu 45-57 arasında olan öğrencilerin program hakkındaki görüşleri ile notu 87-100 arasında olan öğrencilerin görüşleri, notu 87100 arasında olan öğrencilerin lehine anlamlı bir şekilde farklılaştığı görülmüştür ( $U=967,50 ; p=0,01)$.

Programın girdi boyutundan elde edilen bulgulara göre ise gruplar arasında istatistiksel olarak anlamlı bir fark bulunamamıştır.

Elde edilen bulgulardan hareketle, düşük not alan öğrencilerin yüksek not alan öğrencilere göre daha olumsuz bir tutum içerisinde oldukları söylenebilir.
Dolayısıyla öğrencilerin 1.dönem aldıkları notlara göre uzaktan eğitimle yürütülen Yabancı Dil I dersi öğretim programı hakkındaki görüşleri bağlam, süreç ve ürün boyutlarında anlamlı olarak farklılaşırken, girdi boyutunda anlamlı bir farklılığa sahip değildir.

\section{Sonuç ve Öneriler}

Araştırmanın amaçları doğrultusunda öğrencilere uygulanan ölçekten elde edilen bulguların analiz edilmesinin ardından şu sonuçlara varılmıştır:

(i) Öğrencilerin program hakkındaki genel görüşleri olumsuz bir seviyededir.

(ii) Süreç boyutunda öğrenciler daha olumlu görüşlere sahip olmalarına rağmen, bu boyutta bile görüşleri ortalama bir seviyededir. Diğer boyutlar olan girdi, bağlam ve ürün boyutlarında ise öğrenci görüşleri ortalamanın altındadır. Orhan ve Ay (2017), Batı Karadeniz bölgesinde bulunan bir devlet üniversitesinde uzaktan eğitimle yürütülmekte olan Yabanc1 Dil I dersi öğretim programını değerlendirmek amacıyla 2015-2016 öğretim yılında Yabancı Dil I dersini alan 715 birinci sınıf öğrencisi ile yaptıkları çalışmada öğrencilerin Yabancı Dil I dersi öğretim programından orta düzeyde memnun oldukları ve en çok memnun oldukları boyutun süreç boyutu olduğu sonucuna varmışlardır. Süreç boyutunun ardından ise bağlam, girdi ve ürün boyutlarının geldiği görülmüştür. $\mathrm{Bu}$ çalışmanın sonuçları söz konusu araştırmaya yakın sonuçlar vermektedir.

(iii) Öğrenciler, Yabancı Dil I dersinin uzaktan eğitimle verilmesinin İngilizce bilgilerini geliştirmede etkili olmadığı görüşüne sahiptirler. Öte taraftan, Gaziantep Üniversitesi 1.sınıf öğrencilerine uzaktan eğitim yoluyla verilen İngilizce dersine yönelik öğrenci görüşlerini belirlemeye çalışan Şirin (2015), araştırma sonucunda öğrencilerin program hakkında olumlu görüşe sahip olduklarını tespit etmiştir.

(iv) Öğrencilerin diğer maddelere kıyasla daha olumlu görüşlere sahip oldukları maddeler öğretim elemanları ile ilgili maddelerdir. Benzer şekilde, "İngilizce 1" dersine yönelik öğrenci görüşlerini çeşitli değişkenler açısından incelemeyi amaçlayan Ersoy (2015), öğrencilerin çoğunun öğretim elemanı ile ilgili olumlu görüşlere sahip olduğu sonucuna varmıştır.

(v) Programın girdi boyutu hakkında erkekler öğrenciler kadın öğrencilerden daha olumlu görüşlere sahiptir.

(vi) Ücretsiz internet erişimine sahip olan öğrencilerin, ücretsiz internet erişimine sahip olmayan öğrencilere göre süreç boyutunda daha olumlu görüşlere sahip oldukları görülmektedir.

(vii) Birinci dönem alınan notlardan hareketle, daha başarılı olan öğrencilerin programa yönelik bağlam, süreç ve ürün boyutunda daha olumlu görüşlere sahip oldukları görülmektedir.

(viii) Programın süreç boyutu hakkında lisans öğrencileri ön lisans öğrencilerine göre daha olumlu görüşlere sahiptirler. 
Araştırmanın amaçları doğrultusunda öğrencilere uygulanan ölçekten elde edilen bulguların analiz edilmesinin ardından şu önerilerde bulunulabilir:

(i) Uzaktan eğitimle yürütülen Yabancı Dil I dersi öğretim programının tüm boyutlarıyla, özellikle de ürün boyutu yönüyle, geliştirilmesi sağlanabilir.

(ii) Öğretim programının yapılandırılmasında öğrencilerin beklentileri, ihtiyaçları ve İngilizce seviyeleri göz önünde bulundurulabilir.

(iii) Uzaktan eğitimle yürütülen Yabancı Dil I dersi öğretim programına katılacak öğrenciler için uzaktan öğrenme ve internet kullanma konularında bilgilendirme ve yetkinliklerini arttırma amaçlı kapsamlı ve farklı çalışmalar yapılabilir.

(iv) Kişisel bilgisayarı olmayan öğrenciler için ücretsiz internet erişiminin sürekli olduğu üniversite yerleşkelerinde olanaklar arttırılabilir.

(v) Öğrencilere sunulan ve uzaktan eğitim portalına yüklenen öğretim materyali ve kaynakların nicelik ve nitelik olarak zenginleştirilmesi sağlanabilir.

(vi) Uzaktan eğitim portalına yüklenen testlerin sayısı ve çeşitliliği arttırılabilir.

(vii) Programın değerlendirilmesinin ve geliştirilmesinin sürekliliğini sağlamak için programın uygulanmasına yönelik öğrenci görüşleri alınabilir ve anketler uygulanabilir.

\section{Kaynakça}

Al, U., \& Madran, R. O. (2004). Web tabanlı uzaktan eğitim sistemleri: Sahip olması gereken özellikler ve standartlar. Bilgi Dünyasl, 5(2), 259-271.

Alpar, R. (2016). Uygulamall istatistik ve geçerlikgüvenirlik. Ankara: Detay Yayıncılık.

Büyüköztürk, Ş., K1lıç Çakmak, E., Akgün, Ö. E., Karadeniz, Ş., \& Demirel, F. (2016). Bilimsel araştırma yöntemleri. Ankara: Pegem Akademi Yayıncılık.

Can, A. (2017). Spss ile bilimsel araştırma sürecinde nicel veri analizi. Ankara: Pegem Akademi Yayıncılık.

Clark, T. A., \& Verduin Jr, J. R. (1989). Distance Education: Its Effectiveness and Potential Use in Lifelong Learning. Lifelong Learning, 12(4), 24-27.

Demir, E. (2014). Uzaktan Eğitime Genel Bir Bakış. Dumlupınar Üniversitesi Sosyal Bilimler Dergisi, 39, 203-212.

Ersoy, N.Ş. (2015). Uzaktan ingilizce dersinin farkl değişkenler açısından incelenmesi. Ĕgitim ve Öğretim Araştırmaları Dergisi, 4(3), 95-106.

Farooq, M. U., Al Asmari, A., \& Javid, C. Z. (2012). A study of online English language teacher education programmes in distance education context in Pakistan. English Language Teaching, 5(11), 91-103.

Helvacı, M. A. (2010). Okullarımız değişime/yeniliğe ne kadar hazır? Eğitime Bakış Dergisi, 6(17), 47-53.

İşman, A. (2011). Uzaktan ĕgitim. Ankara: Pegem Akademi.
Karasar, N. (2016). Bilimsel araștırma yöntemi. Ankara: Nobel Akademik Yayıncılık.

Keegan, D. (1996). Foundations of distance education. London: Routledge.

Kutluca, T., \& Ekici, G. (2010). Öğretmen adaylarının bilgisayar destekli eğitime ilişkin tutum ve öz-yeterlik algılarının incelenmesi. Hacettepe Üniversitesi Ĕ̆itim Fakültesi Dergisi, 38(38), 177-188.

Orhan, A. (2016). Uzaktan eğitimle yürütülen yabancı dil dersi ögretim programının bağlam, girdi, süreç ve ürün (cipp) modeli ile değerlendirilmesi. Yüksek Lisans Tezi. Düzce: Düzce Üniversitesi.

Orhan, A., \& Ay, Ş. Ç. (2017). Investigating Students' Perspectives of Foreign Language Distance Education Curriculum According to Some Variables. Journal of Education and Training Studies, 5(4), 190-203.

Şirin, R. (2015). Ingilizce dersinin uzaktan eğitimine yönelik öğrenci görüşleri. Yüksek Lisans Tezi. Adana: Çukurova Üniversitesi.

Ural, A., \& Kılıç, İ. (2010). Bilimsel araştırma süreci ve spss ile veri analizi. Ankara: Detay Yayınc1lık.

Uzaktan Eğitim (2014). Uzaktan eğitimin geleneksel eğitimle karşılaştırılması. (Erişim: 01/06/2017), https:// www.uzaktanegitim.com/haberler/uzaktan-egitimin-gele neksel-egitimle-karsilastirilmasi-/102

Yıldırım, A., \& Şimşek, H. (2016). Sosyal bilimlerde nitel araştırma yöntemleri. Ankara: Seçkin Yayıncılık.

YÖK (2013). Yükseköğretim kurumlarında uzaktan öğretime ilişkin usul ve esaslar. (Erişim: 01/06/2017), https://www.yok.gov.tr/documents/10279/34559/uzakta n_ogretim_esas_usul.pdf/ 